\title{
Birds as Landscape Elements in Urban Parks: A Comparative Study on the Perception between Indonesian and Japanese People
}

\author{
Sry Wahyuni ${ }^{1,2 *}$, Katsunori Furuya ${ }^{2}$ \\ ${ }^{1}$ Landscape Architecture Program, Graduate School of Bogor Agricultural University, Dramaga, Bogor, Indonesia \\ ${ }^{2}$ Division of Environmental Science and Landscape Architecture, Graduate School of Horticulture, Chiba University, \\ Matsudo, Chiba, Japan
}

\begin{abstract}
Birds are both a landscape element and a common form of wildlife found in urban parks. Human's perceptions of their surrounding landscapes need to be understood in order to create better environments. This study aimed to determine and evaluate the aesthetic quality of landscapes regarding birds as landscape elements, and to compare the results between Indonesian and Japanese people. The data were analyzed using scenic beauty estimation, the Mann-Whitney $U$ Test, and the Spearman Correlation. A total of 252 respondents evaluated landscape images and answered a questionnaire. The results showed that landscape images with birds were given lower scenic beauty scores from Japanese respondents than they were from Indonesian respondents. There were significant differences between Indonesian and Japanese respondents in four landscape images with birds and two landscape images with human-bird interactions. Besides this, there were different strengths in correlations between landscape images with and without birds and landscape images with and without human-bird interactions among Indonesian and Japanese respondents. In conclusion, the existence of birds as landscape elements in urban parks had an influence on the perceptions and preferences of Indonesian and Japanese respondents. However, there was a difference in how they appreciated birds as landscape elements.
\end{abstract}

Keywords: cross-cultural, landscape images, preference, scenic beauty estimation, urban wildlife

\section{INTRODUCTION}

Public awareness about comfortable, habitable, and sustainable environments has become an important aspect in urban development. Developing sustainable cities is not only about improving the abiotic and biotic aspects of urban life, but also improving social aspects of life such as citizens' satisfaction with, experiences of, and perceptions of their environmental quality. In various definitions of sustainable cities, quality of life issues are important in addition to environmental criteria. Features such as the "number of public green spaces" and "public parks" are often mentioned as important factors that make cities livable, pleasant, and attractive [1]. The President of The Trust for Public Land in America, Will Rogers, explained that great cities are known for their great parks, and one measure of any city's greatness is its ability to provide recreation, natural beauty, and signature open spaces for its citizens [2]. Urban parks are green open spaces in the urban landscape and are mostly dominated by vegetation and water; most parks are large, but there are also smaller parks such as "pocket parks". Usually, parks are locally defined by

Corresponding address:

Sry Wahyuni

Email : srywahyuniii@gmail.com

Address : Jalan Damai Blok O No.2 Purwodadi Indah, Panam, Pekanbaru, Riau, Indonesia, 28296 authorities and are generally reserved for public use [3]. Referring to many studies, urban parks provide various benefits for humans, such as health (both mental and physical) and well-being, social cohesion, tourism, recreation, and aesthetics [4-10].

Humans and landscapes are important components of landscape perception. Perception can guide humans' actions with respect to objects [11]. There are many factors that can affect human perception towards an object or landscape. The human component encompasses past experiences, knowledge, expectations, and the socio-cultural (individuals and groups), while the landscape component includes individual elements and landscapes as entities [12]. Studies of public perceptions of landscapes have been a multidisciplinary venture with contributions from both natural and social sciences [13]. Recent studies have stated that there are many variables that may affect human perception and preference such as individual understandings of visual quality, cultures, hobbies, knowledge backgrounds, experiences, living environments, social roles, classes, and economic incomes [14]. Other studies have found that factors that influenced human perception consisted of gender, age, the types of landscapes in which people lived in the past, the types of landscapes in which people live in the present, the present urbanization level, and experiences during the journeys to the landscapes [15]. 
Landscape elements play an important role in human perceptions of a landscape. Findings from research in Sapporo, Japan revealed that flowers were the most preferred landscape element for street vegetation and were seen as not only contributing to the aesthetic quality of the landscape, but also had a positive influence on psychological well-being [16]. In research regarding visual and environmental quality perception and preference among people from three countries (China, France, and Portugal), images with wildflowers and wildlife scored quite favorably with French and Portuguese respondents [14]. Birds are a landscape element that can be found in urban parks. They are also a common form of wildlife in urban landscapes that use urban parks as their habitat. Parks can support birds' lives by providing a place for nesting, resting, breeding, playing, and more. Birds can be used as indicators of environmental quality because they can respond to environmental changes quickly, even when such changes cannot be observed or predicted by measuring a limited set of pre-selected physical or chemical parameters $[17,18]$.

Most studies on birds have focused on their diversity and community composition, their community structure from urban to natural habitats, their ecological function, their distribution and habitat in urban landscapes, and the conceptual framework for conservation in urban landscapes [19-26]. However, studies focusing on the human perception of birds as landscape elements across several countries are rarely done. People who live in urban areas usually have less time to experience and spend time in nature, so urban parks can be the one green open space that provides them with a place to contact nature in urban landscapes. Therefore, it is important to understand their perceptions of the surrounding landscape in order to create a better environment, especially in urban parks. Findings from this study can be used as basic information for planning, designing, and/or managing urban parks.

In this study, we attempted to determine human perceptions and evaluate the aesthetic quality of landscapes with birds as landscape elements in urban parks. We also compared the perception and aesthetics value of birds as landscape elements in urban parks between Indonesian and Japanese people. The general hypothesis of this study was that nationality has an influence on human perception. The specific hypotheses were as follows: first, existence of birds as landscape elements has an influence on human perceptions and evaluations of landscape aesthetics. Second, interaction between humans and birds has an influence on human perceptions and evaluations of landscape aesthetics.

\section{METHODS}

To determine human perceptions of birds as landscape elements, we used a questionnairebased evaluation to address the following topics: frequency of park visit, purpose of park visit, motive of watch the birds, and attitudes toward birds. Besides this, we also used a photographbased to evaluate the aesthetic qualities of landscapes with birds as landscape elements [2731]. The responses to those questions are important for answering this research hypotheses, which was stated in the introduction.

\section{Data Collection}

The sampling method applied in this study was purposive sampling, with respondent groups consisting of Indonesian and Japanese people. The selected respondents have varied educational backgrounds. These types of respondents were selected because the purpose of this study was to determine the perceptions of general public park users. The total number of respondents was 252 (consisting of 135 Indonesians and 117 Japanese). In Japan, the data were obtained through a questionnaire survey, while Indonesian respondents were given an online questionnaire. The questionnaire was prepared using their native language to ensure equal understanding of questionnaire. The presurvey was conducted between April and May 2015, while the survey was conducted between June and August 2015.

In this questionnaire, respondents were asked to complete two sections. In the first section, respondents were asked to evaluate 10 representative landscape images on a scale ranging from "strongly like and very high scenic beauty" (10) to "strongly dislike and very low scenic beauty" (1). There were 10 landscape images consisting of 7 original images and 3 modified images (Figure 1). The landscape images were taken on a clear day during the presurvey in April 2015 in Chiba Park, Japan. Those landscape images were added to the questionnaire in a random order, between original and modified images. In the second section, respondents were queried about their personal information and perceptions toward birds as landscape elements. The questionnaire 
survey method can provide an evaluation or assessment of landscape quality from public perspectives in more efficient and economical ways [27].

\section{Data Analysis}

The analysis method applied in this study consisted of three steps: 1) Scenic Beauty Estimation (SBE) [27]. SBE was applied to determine and evaluate the aesthetic quality of landscapes with birds as landscape elements, from human perceptions and preferences, between Indonesian and Japanese respondents. 2) Mann-Whitney $U$ Test. The Mann-Whitney $U$ Test was applied to test significant differences between Indonesian and Japanese respondents. 3) Spearman Correlation. The Spearman Correlation was applied to determine the strength and direction of the monotonic relationship between landscape images with and without birds and landscape images with and without human-bird interactions among Indonesian and Japanese respondents.

\section{RESULT AND DISCUSSION}

\section{Characteristics of Respondents}

A total of 252 respondents participated in this study, consisting of 135 Indonesians and 117 Japanese. Survey results (Figure 2) showed that among the Indonesian respondents, there were more females (69.63\%) than males $(30.37 \%)$; conversely, there were more males (60.68\%) than females (39.32\%) among the Japanese respondents. A majority of Indonesian respondents received university education in undergraduate $(79.26 \%)$ and graduate levels (18.52\%). Among the Japanese respondents, about $96.58 \%$ received university education at the undergraduate level and $3.24 \%$ received university education at the graduate level. A majority of Indonesian (92.59\%) and Japanese $(99.15 \%)$ respondents were between $18-25$ years old.

In this study, there was a difference in factors that affect human perceptions and preferences for birds as landscape elements in urban parks. The Mann-Whitney $U$ Test revealed that there were significant differences in perceptions and preferences between Indonesian and Japanese respondents. However, there were no significant differences in perceptions and preferences between male and female respondents from both countries. It can be concluded that in this study, nationality had an influence, while gender had no influence, on human perceptions and preferences for birds as landscape elements in urban parks. Results obtained correspond with previous research regarding factors that affect human perceptions and preferences, which shows that social context and cultural influences might affect the general perspectives of people [14].

\section{Comparison of Perception and Preference for Birds as Landscape Elements between Indonesian and Japanese People}

Survey results showed that the majority of Indonesian respondents (98.52\%) and all Japanese respondents (100\%) had ever visited park. A majority of Indonesian respondents visited a park less than once a month $(50.37 \%)$ and spent one and a half hours or less there (53.33\%). Among the Japanese respondents, about $45.30 \%$ visited a park once a month and $71.79 \%$ spent one and a half hours or less there.

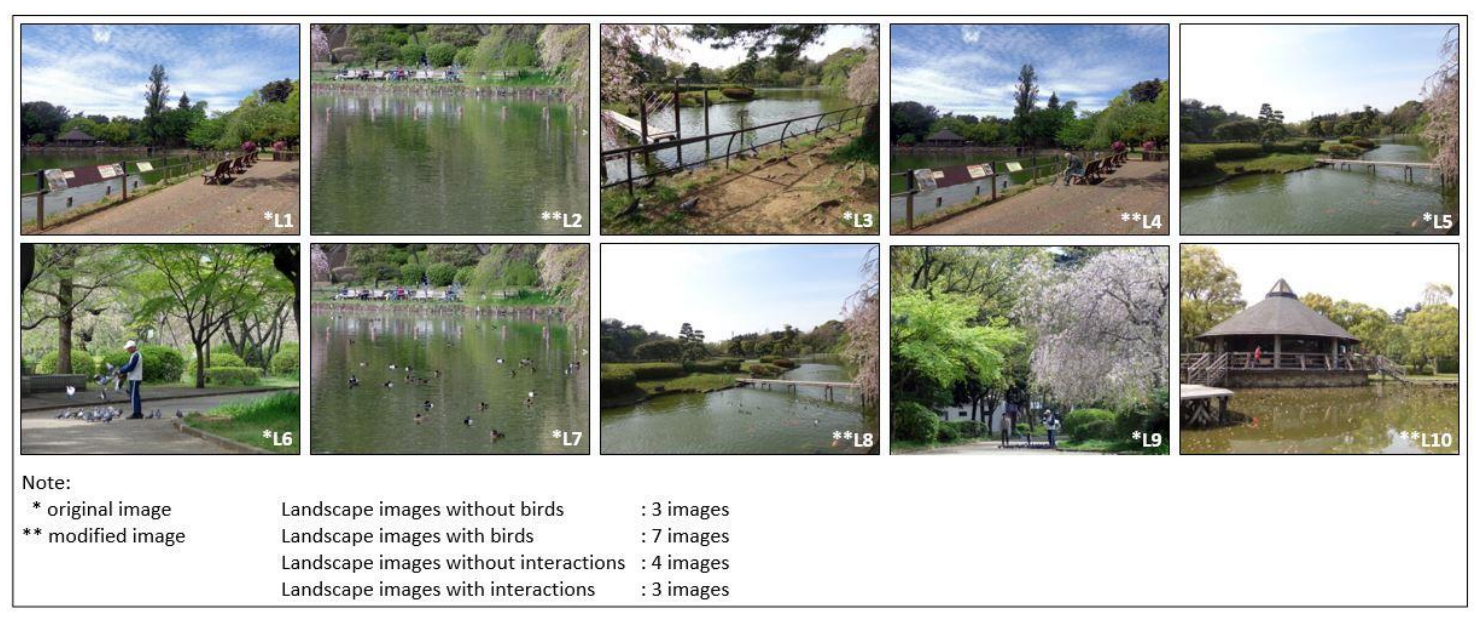

Figure 1. Landscape images without birds (L1, L2, L5), with birds $(L 3, L 4, L 6, L 7, L 8, L 9, L 10)$, without interactions $(L 3, L 7, L 8$, L10), and with interactions (L4, L6, L9). 


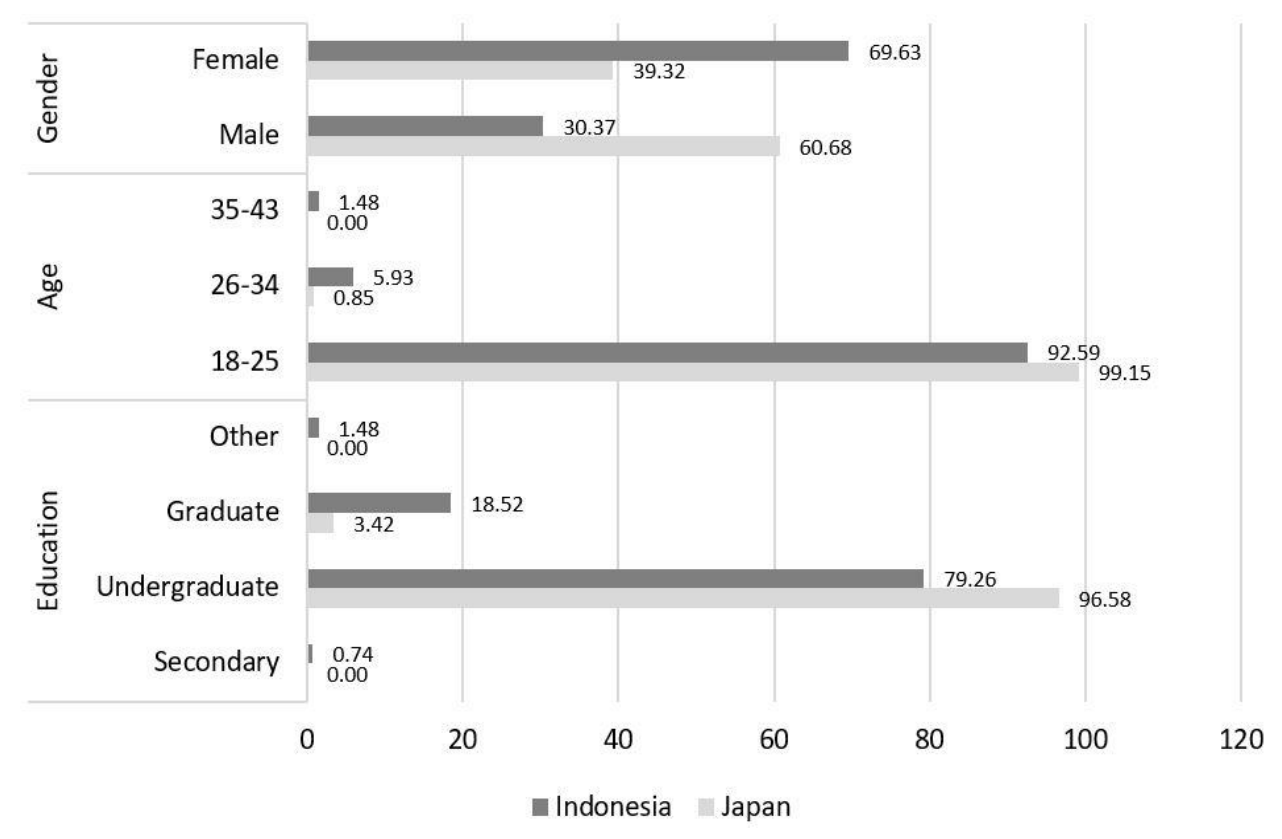

Figure 2. Respondents' characteristics.

These results indicated that Indonesian respondents were not using parks as frequently as Japanese respondents. These findings may be explained by the facts that the present parks in Indonesia are insufficient in number and highly unequal distribution [32-36]. In most Indonesian cities, barely any good-quality parks exist in neighborhoods. Due to various urban developments, the presence of high-quality parks - including well-planned and well-maintained are barely found. This situation is different than in Japan, parks tended to be more equitably distributed, located close to the residence, and has a good quality. Earlier researches pointed out that in many Indonesian cities, the current situation of green open spaces is alarming [34]. Cities will continue to grow, and features such as the "green open spaces", "public parks", and "amounts of public green open spaces" will continue to be a vital part of urban areas. Providing parks for citizens is increasingly challenged by the limited amount of available park space in urban areas where land is very expensive [37].

The results revealed that $6.13 \%$ of Indonesian respondents and $3.24 \%$ of Japanese respondents visited a park for the purpose of bird watching. A majority of Indonesian respondents participated in bird watching to take photos or videos of birds (44.50\%), about $33.51 \%$ to enjoy watching the birds themselves, and about $18.32 \%$ to improve their knowledge. Besides this, a majority of Japanese respondents participated in bird watching to enjoy watching the birds themselves (49.62\%), about $23.31 \%$ to take photos or videos of birds, and about $10.53 \%$ to improve their knowledge. These results indicated that Indonesian respondents were more attracted to birds than those of Japanese respondents. People's motives to visit natural areas and the various activities they carry out reflect the demands people place on natural areas [1]. In this study, respondents' demands on bird watching activity were not so high, yet Indonesian respondents' demands were higher than Japanese respondents. These findings may be explained by the facts that the Indonesian public tended to be attracted to animals and the existence of animals is a major reason to revisit natural areas [38]. Consistent with the findings of previous research in Pekanbaru, Indonesia, the existence of birds can attract visitor to parks [39].

A majority of Indonesian respondents agreed that birds are interesting (94.07\%), enjoyed having interactions with birds in parks (88.15\%), and did not feel disturbed by their presence in parks (92.31\%). Among the Japanese respondents, about $65.81 \%$ agreed that birds are interesting, $64.10 \%$ enjoyed having interactions with birds in parks, and $65.81 \%$ did not feel disturbed by their presence in parks. These percentages were much lower than those of Indonesian respondents. These results indicated that the Indonesian respondents expressed more interest in birds as landscape elements in parks than those of Japanese respondents. Results 
obtained correspond with previous research in Bogor, Indonesia, the Indonesian public described birds as interesting elements of nature, and they showed interest in birds [40]. Earlier research in Pekanbaru, Indonesia also revealed that the Indonesian public tended to like green open spaces in which there are birds. Respondents mentioned that the existence of birds in parks can help to relieve stress and make them feel closer to nature [39]. Meanwhile, findings from research in Japan revealed that Japanese people's experiences with many animals in nature is decreasing, especially among younger generations. In 2002 and 2012, birds were ranked highest as "the most often seen" wildlife among the Japanese public (university students). Respondents often saw crows and sparrows in urban areas. In contrasts, birds were not chosen as "the most favorite wildlife", and their popularity decreased in 2012, when mammals were chosen as the most popular wildlife [41].

The results revealed that in evaluating scenic beauty (Figure 3), Japanese respondents tended to give lower scenic beauty scores for five landscape images with birds ( $\mathrm{L} 3=40.14, \mathrm{~L} 4=33.40$, $\mathrm{L} 6=-9.29, \quad \mathrm{~L} 7=26.69$, and $\quad \mathrm{L} 9=35.35)$ than Indonesian respondents $(\mathrm{L} 3=85.77, \quad \mathrm{~L} 4=37.69$, $\mathrm{L} 6=88.86, \mathrm{~L} 7=71.17$, and $\mathrm{L} 9=95.17)$. Besides this, Japanese respondents also tended to give lower scenic beauty scores for all landscape images with human-bird interactions (L4=33.40, L6=9.29, and $L 9=35.35)$ than Indonesian respondents (L4=37.69, L6=88.86, L7=71.17, and L9=95.17).
These results indicated that in this study, there were differences in perceptions and preferences between Indonesian and Japanese respondents. Japanese respondents had less aesthetic appreciation for landscape images that featured birds as landscape elements, especially with human-bird interactions, than those of Indonesian respondents. Results obtained correspond with previous research in Japan, the Japanese people's experiences with many animals in nature is decreasing, especially among younger generations. Moreover, birds were not so popular than other animals among younger generations [41]. Furthermore, Japanese respondents had less aesthetic appreciation for landscape images with human-bird interactions than Indonesian respondents. These findings may be explained by the facts that there are regulations against feeding birds in parks in Japan. This situation is different than in Indonesia, parks are mostly do not have regulations against feeding birds.

However, it has long been known that the Japanese culture has a high appreciation for nature, live in amicable intimacy with nature, and it was often reflected in their daily life [41, 42]. Furthermore, there is a close relation between an aesthetic appreciation of nature and the religion in Japan. Despite the love and appreciation for nature, the Japanese have tried to control and dominate nature in various ways. Equal notice is being given to the environmental degradation caused by the Japanese at home as well as abroad [44, 45].

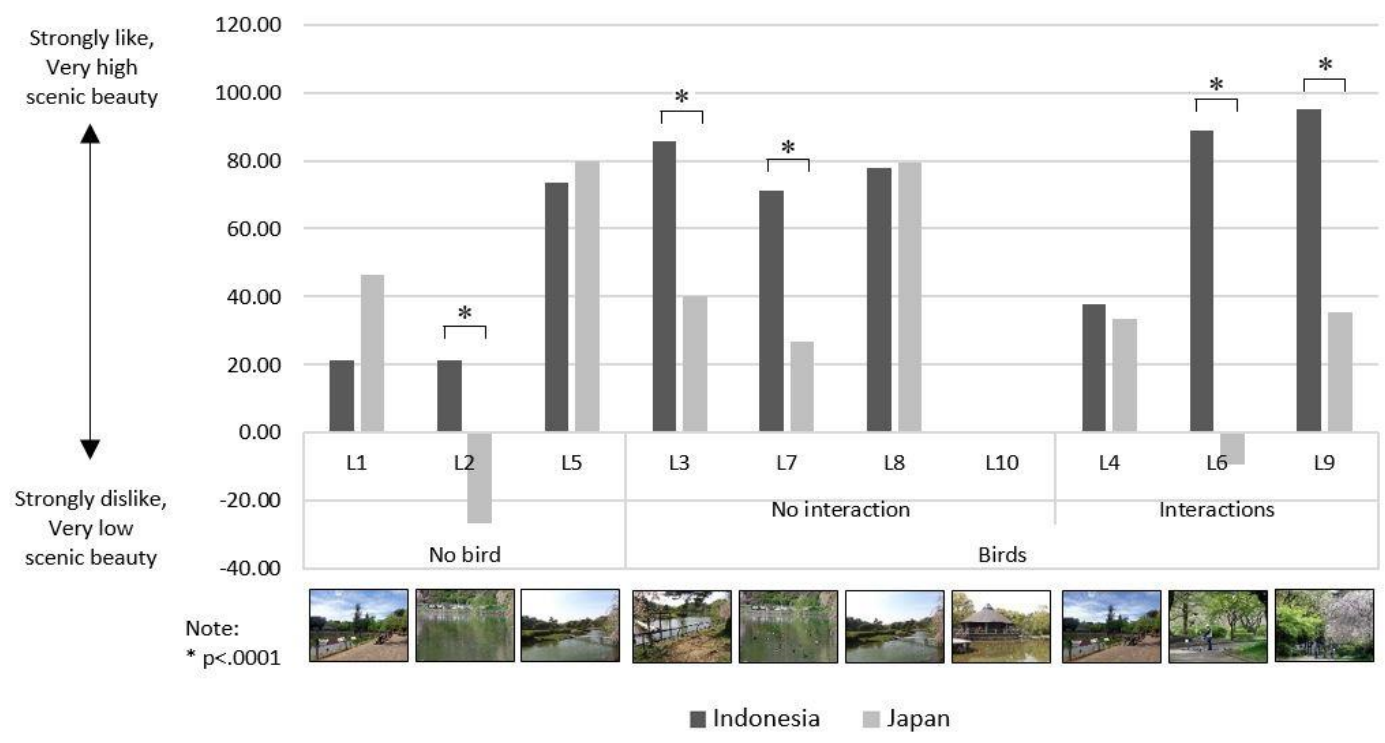

Figure 3. SBE value of landscape images without birds, with birds, without human-bird interactions, and with human-bird interactions. 
Table 1. Mann-Whitney U Test of landscape images between two countries

\begin{tabular}{|c|c|c|c|c|c|c|c|c|c|c|}
\hline \multirow{3}{*}{ Landscape Images } & \multirow{2}{*}{\multicolumn{3}{|c|}{ Without Birds }} & \multicolumn{7}{|c|}{ With Birds } \\
\hline & & & & \multicolumn{4}{|c|}{ Without Interactions } & \multicolumn{3}{|c|}{ With Interactions } \\
\hline & L1 & $\mathbf{L 2}$ & $\mathbf{L 5}$ & L3 & L7 & L8 & L10 & L4 & $\mathrm{L} 6$ & L9 \\
\hline Std Err Dif & 8.9688 & 9.0720 & 8.9678 & 9.0602 & 9.0771 & 8.9707 & 9.0958 & 9.0259 & 9.0971 & 9.0628 \\
\hline Mann-Whitney U & 0.1680 & $0.0000 *$ & 0.8323 & $0.0000^{*}$ & $0.0000^{*}$ & 0.0848 & 0.0609 & 0.1480 & $0.0000^{*}$ & $0.0000^{*}$ \\
\hline
\end{tabular}

Note: ${ }^{*} p<.0001$, also tested using the Steel-Dwass Test

In studies regarding Japanese perceptions of wildlife, the Japanese public expressed less ethical or ecological concern for nature and wildlife. Among the Japanese public, having a primary interest in, strong appreciation, affection, and emotional attachments for individual animals such as pets or large wild animals were quite common. The Japanese public described their preferences for nature as a "love of artificial and symbolic nature". They preferred to have contact with nature from a "controlled and safe distance". In other words, the Japanese appreciation for nature was very limited and idealized [46]. In contrast, findings from a study in Bogor, Indonesia revealed that the Indonesian public showed no preferences for individual animals such as specific bird species [47].

The Mann-Whitney $U$ Test (Table 1 ) revealed that there were significant differences in perceptions and preferences for five landscape images (L2, L3, L6, L7, and L9) between Indonesian and Japanese respondents. Landscape image two (L2) was a modified version of landscape image seven (L7), which featured birds. Landscape image three (L3) and seven (L7) were original images that featured birds without human-bird interactions. Besides this, landscape image six (L6) and nine (L9) were original images that featured birds with human-bird interactions. It can be concluded that in this study, of the ten landscape images, only one image without birds and four images that featured birds with and without human-bird interactions as landscape elements in parks showed significant differences between Indonesian and Japanese respondents.

The Spearman Correlation (Figure 4) revealed that there were moderate-to-very strong correlations between landscape images with ( $L 3$, L4, L6, L7, L8, L9, and L10) and without birds (L1, $\mathrm{L} 2$, and $\mathrm{L} 5$ ) among Indonesian respondents. The highest correlation between landscape images with and without birds ( $p=0.8494)$ was detected between landscape images four and one (L4-L1). Landscape image four (L4) was a modified version, featuring birds, of landscape image one (L1). Besides this, there were also weak-to-strong correlations between landscape images with (L4,
L6, and L9) and without human-bird interactions (L3, L7, L8, and L10) among Indonesian respondents (Figure 5). The highest correlation between landscape images with and without human-bird interactions ( $p=0.6495)$ was detected between landscape images seven and four (L7L4). Landscape image four (L4) was a modified image that featured human-bird interactions. Meanwhile, landscape image seven (L7) was an original image that featured birds, but without human-bird interactions. It can be concluded that in this study, the existence of birds as landscape elements and human-bird interactions in urban parks have an influence on and correlate positively with the perceptions and preferences of Indonesian respondents.

In contrast, The Spearman Correlation (Figure 4) revealed that there were moderate-to-very weak correlations between landscape images with (L3, L4, L6, L7, L8, L9, and L10) and without birds (L1, L2, and L5) among Japanese respondents. The lowest correlation between landscape images with and without birds $(p=-$ 0.2382 ) was detected between landscape images six and five (L6-L5). Landscape image five (L5) was an original image without birds, and landscape image six (L6) was an original image that featured human-bird interactions. Besides this, there were also weak-to-very weak correlations between landscape images with ( $L 4$, L6, and L9) and without human-bird interactions (L3, L7, L8, and L10) among Japanese respondents. The lowest correlation between landscape images with and without human-bird interactions ( $p=-0.1216)$ was detected between landscape images eight and four (L8-L4). Landscape image four (L4) was a modified image that featured human-bird interactions, and landscape image eight (L8) was a modified image that featured birds, but without human-bird interactions. It can be concluded that in this study, the existence of birds as landscape elements and human-bird interactions in urban parks did not have much influence on the perceptions and preferences of Japanese respondents, and some could even correlate negatively with the perceptions and preferences. 


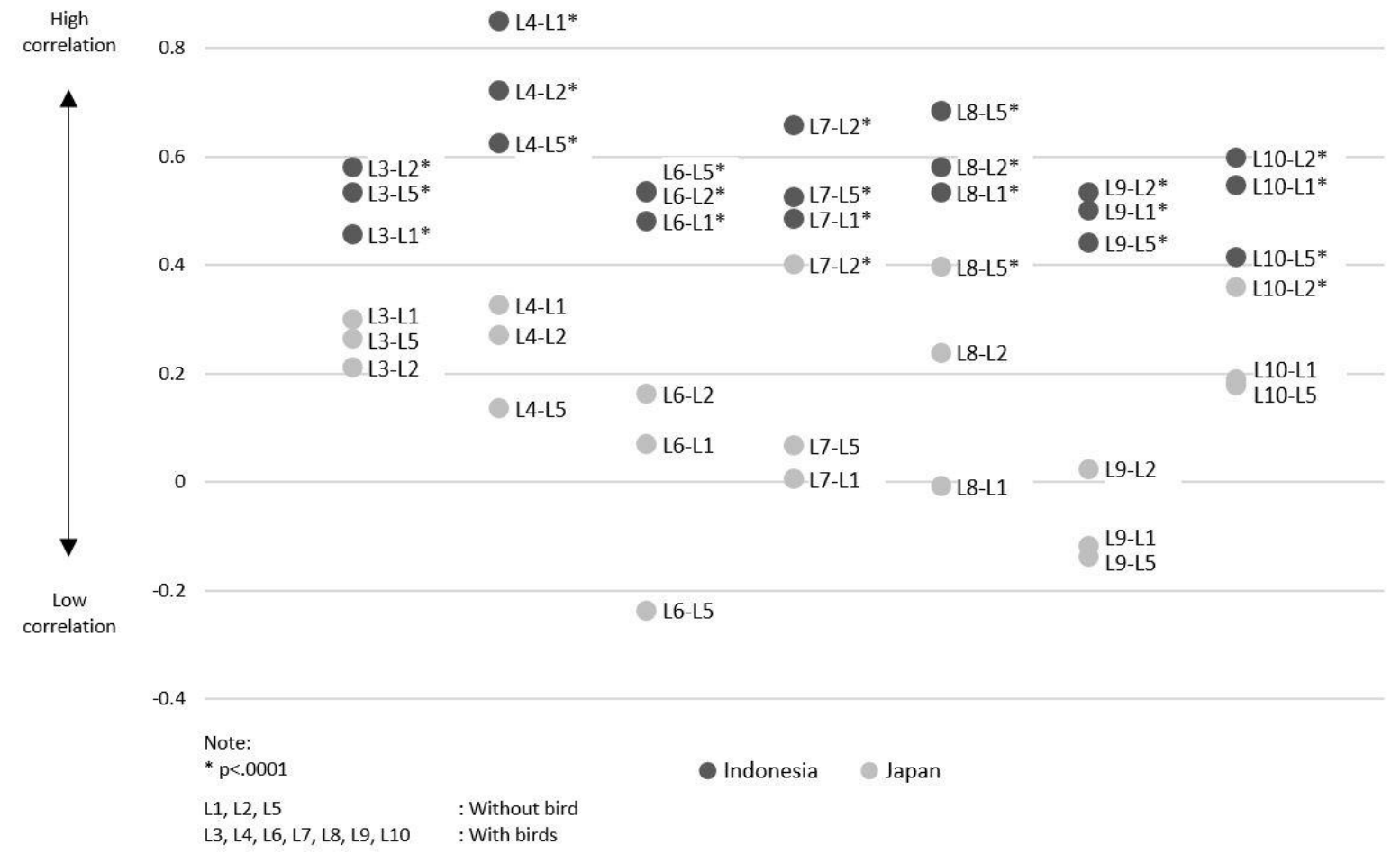

Figure 4. Spearman correlation of landscape images with and without birds among two countries.

0.8
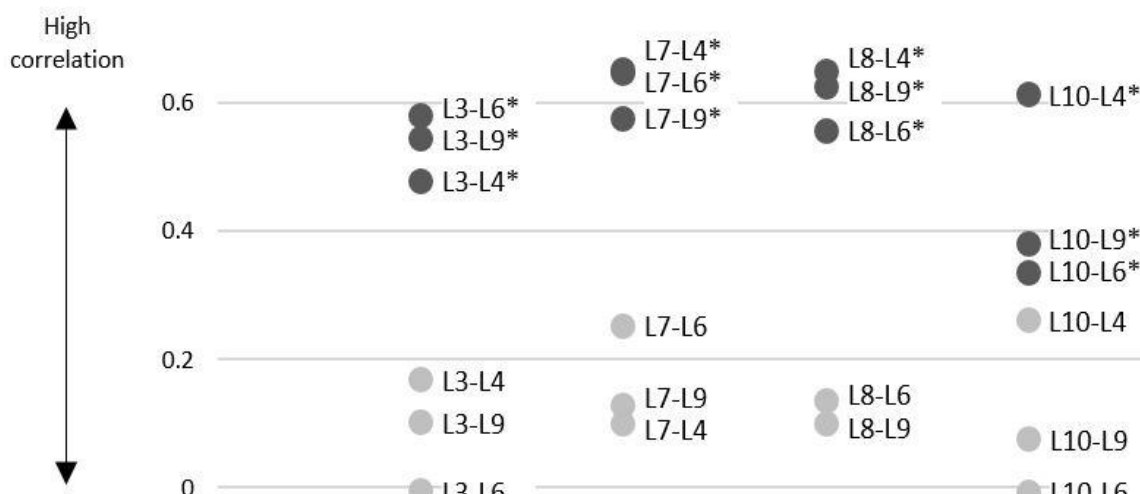

0.4

L10-L6*

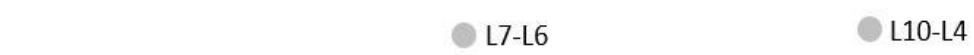

0.2

L7-L6

L8-L6

L8-L9 L10-L9

0

L7-L9
L7-L4

L10-L9

Low correlation

L8-L4

$-0.2$

Note:

* $\mathrm{p}<.0001$

Indonesia Japan

L3, L7, L8, L10 : Without interaction

L4, L6, L9 : : With interactions

Figure 5. Spearman correlation of landscape images with and without human-bird interactions among two countries. 
Studies regarding people's responses towards natural landscapes among university students of Japan and Indonesia showed that the concept of novelty and familiarity could affect the preferences of the Indonesian public (university students). Moreover, they liked "unusual" and "never-before-seen landscapes" in their country. In contrast, the Japanese public (university students) liked "familiar landscapes" [48]. Other findings also revealed that even though the Japanese public showed an interest in wildlife, they preferred to enjoy direct experiential contact with nature from a safe distance. In addition, they did not show a high primary concern for the interrelationships between wildlife species and environments as a system [46].

\section{Limitations}

The total number of landscape images (10) and respondents (252) in this study were limited. It would be better if the total number of landscape images and respondents were bigger, especially for statistical analysis. The selected landscape images in this study were located only in Japan, because we hardly found ideal urban parks featuring wild birds in Indonesia. Although the hypotheses were answered, this might weaken the conclusions for each country. In this study, factors that influenced respondents' perceptions and preferences were not investigated deeply apart from nationality and gender. Other factors such as age, occupation, education, living environment, and park visiting patterns would be useful for understanding the perceptions and preferences more deeply. Thus, related research is strongly recommended.

\section{CONCLUSION}

In this study, a majority of respondents agreed that birds are interesting and did not feel disturbed by their presence in parks. There were significant differences in the responses of Indonesian and Japanese respondents to four landscape images that featured birds and two landscape images that featured human-bird interactions. In evaluating scenic beauty, Japanese respondents tended to give less aesthetic appreciation for five of the six landscape images featuring birds than Indonesian respondents. It was evident that in this study, nationality had an influence on human perceptions and preferences. Besides this, there were moderate-to-very strong correlations (landscape images with and without birds) and weak-to-strong correlations (landscape images with and without human-bird interactions) among Indonesian respondents. Conversely, there were moderate-to-very weak correlations (landscape images with and without bird) and weak-to-very weak correlations (landscape images with and without human-bird interactions) among Japanese respondents. It was evident that in this study, the existence of birds as landscape elements and human-bird interactions in urban parks have an influence on the perceptions and preferences of people from both Indonesia and Japan. However, there was a difference in how respondents from the countries appreciated birds as landscape elements. These findings are useful for understanding human perceptions and preferences for birds as landscape elements in urban parks. This research is particularly useful for landscape architects in planning, designing, and/or managing urban parks.

\section{RECOMMENDATION}

The findings from this study provide a basic information for understanding urban parks issues related to birds as landscape elements from people's perspective. It is clear that in this study, the existence of birds as landscape elements in urban parks have an influence on the perceptions and preferences of Indonesian and Japanese people. Therefore, urban parks authorities should be sensitive enough to meet people's needs and provide high quality landscapes in urban areas.

\section{ACKNOWLEDGEMENT}

The authors would like to thank all anonymous respondents in our studies. We sincerely thank the editor and anonymous reviewers for their comments and suggestions.

\section{REFERENCES}

[1]. Chiesura, A. 2004. The Role of Urban Parks for the Sustainable City. Landscape and Urban Planning. 68. 1:129-138.

[2]. Harnik, P. 2006. The Excellent City Park System: What Makes It Great and How to Get There. The Trust for Public Land. Washington.

[3]. Annerstedt, M., Nielsen, B., Maaruthaveeran, S., and Konijnendijk, C. 2012. Benefits of Urban Parks: A Systematic Review. IFPRA World. 2012.6:10-12.

[4]. Abkar, M., Mustafa Kamal, M.S., Mariapan, M., Maulan, S., and Sheybani, M. 2010. The Role of Urban Green Spaces in Mood 
Change. Australian Journal of Basic and Applied Science. 4. 10:5352-5361.

[5]. Annerstedt, M., Nielsen, B., Maaruthaveeran, S., and Konijnendijk, C. 2013. Benefits of Urban Parks: A Systematic Review. International Federation of Parks and Recreation Administration (IFPRA). Copenhagen.

[6]. Björk, J., Albin, M., Grahn, P., Jacobsson, H., Ardö, J., Wadbro, J., and Östergren, P-O. 2008. Recreational Values of The Natural Environment in Relation to Neighbourhood Satisfaction, Physical Activity, Obesity and Wellbeing. Journal of Epidemiology and Community Health. 62. 4:e2.

[7]. Fuller, R.A., Irvine, K.N., Devine-Wright, P., Warren, P.H., and Gaston, K.J. 2007. Psychological Benefits of Greenspace Increase with Biodiversity. Biology Letters. 3. 4:390-394.

[8]. Maas, J., van Dillen, S.M.E., Verheij, R.A., and Groenewegen, P.P. 2009. Social Contacts as a Possible Mechanism Behind The Relation Between Green Space and Health. Health \& Place. 15. 2:586-595.

[9]. Sherer, P.M. 2006. The Benefits of Parks: Why America Needs More City Parks and Open Space. The Trust for Public Land. San Francisco.

[10]. Wong, K-K. and Domroes, M. 2004. User's Perception of Kowloon Park, Hong Kong: Visiting Patterns and Scenic Aspects. Chinese Geographical Science. 14. 3:269275.

[11]. Blake, R. and Sekuler, R. 2006. Perception. McGraw-Hill. New York.

[12]. Zube, E.H., Sell, J.L., and Taylor, J.G. 1982. Landscape Perception: Research, Application, and Theory. Landscape Planning. 9. 1:1-33.

[13]. Scott, A. J. 2006. Assessing Public Perception of Landscape: Past, Present, and Future Perspectives. $C A B$ Reviews: Perspectives in Agriculture, Veterinary Science, Nutrition, and Natural Resources. 41:1-8.

[14]. Mo, F., Le Cléach, G., Sales, M., Deyoung, G., and Burley, J. B. 2011. Visual and Environmental Quality Perception and Preference in the People's Republic of China, France, and Portugal. International Journal of Energy and Environment. 5. 4:549-555.

[15]. Pratiwi, P.I., Sulistyantara, B., Gunawan, A., and Furuya, K. 2014. A Comparative Study on The Perception of Forest Landscape Using LIST Method Between University Students of Japan and Indonesia. Journal of Tropical Forest Management. 20. 3:167178.

[16]. Todoreva, A., Asakawa, S., and Aikoh, T. 2004. Preferences for and Attitudes towards Street Flowers and Trees in Sapporo, Japan. Landscape and Urban Planning. 69. 4:403416.

[17]. Furness, R.W., Greenwood, J.J.D., and Jarvis, P.J. 1993. Birds as Monitors of Environmental Change. Furness RW, Greenwood JJD, editor. Chapman \& Hall. London.

[18]. Koskimies, P. 1989. Birds as A Tool in Environmental Monitoring. Annales Zoologici Fennici. 26:153-166.

[19]. Gatesire, T., Nsabimana, D., Nyiramana, A., Seburanga, J.L., and Mirville, M.O. 2014. Bird Diversity and Distribution in Relation to Urban Landscape Types in Northern Rwanda. The Scientific World Journal. 2014.

[20]. Huste, A. and Boulinier, T. 2011. Determinants of Bird Community Composition on Patches in The Suburbs of Paris, France. Biological Conservation. 144. 1:243-252.

[21]. Maeda, T. 1998. Bird Communities and Habitat Relationships in a Residential Area of Tokyo. Journal of the Yamashina Institute for Ornithology. 30. 2:83-100.

[22]. McCaffrey, R.E. and Mannan, R.W. 2012. How Scale Influences Birds' Responses to Habitat Features in Urban Residential Areas. Landscape and Urban Planning. 105. 3:274280.

[23]. Melles, S., Glenn, S., and Martin, K. 2003. Urban Bird Diversity and Landscape Complexity: Species-Environment Associations Along a Multiscale Habitat Gradient. Conservation Ecology. 7. 1.

[24]. Mikami, O.K. and Mikami, K. 2014. Structure of The Japanese Avian Community from City Centers to Natural Habitats Exhibits a Globally Observed Pattern. Landscape and Ecological Engineering. 10. 2:355-360.

[25]. Sulaiman, S., Mohamad, N.H.N., and Idilfitri, S. 2013. Contribution of Vegetation in Urban Parks as Habitat for Selective Bird Community. Procedia-Social and Behavioral Sciences. 85:267-281.

[26]. Fernandez-Juricic, E. and Jokimäki, J. 2001. A Habitat Island Approach to Conserving Birds in Urban Landscapes: Case Studies 
from Southern and Northern Europe. Biodiversity and conservation. 10. 12:2023-2043.

[27]. Daniel, T.C. and Boster, R.S. 1976. Measuring Landscape Esthetics: The Scenic Beauty Estimation Method. USDA Forest Service Research Paper RM-167. Rocky Mountain Forest and Range Experiment Station. Fort Collins.

[28]. Anderson, L.M. and Schroeder, H.W. 1983. Application of Wildland Scenic Assessment Methods to the Urban Landscape. Landscape Planning. 10. 3:219-237.

[29]. Akbar, K.F., Hale, W.H., and Headley, A.D. 2003. Assessment of Scenic Beauty of the Roadside Vegetation in Northern England. Landscape and Urban Planning. 63. 3:139144.

[30]. Bulut, Z., Karahan, F., and Sezen, I. 2010. Determining Visual Beauties of Natural Waterscapes: A Case Study for Tortum Valley (Erzurum/Turkey). Scientific Research and Essays. 5. 2:170-182.

[31]. Deng, S., Yan, J., Guan, Q., and Katoh, M. 2013. Short-term Effects of Thinning Intensity on Scenic Beauty Values of Different Stands. Journal of Forest Research. 18. 3:209-219.

[32]. Rijal, S. 2008. Kebutuhan Ruang Terbuka Hijau di Kota Makassar tahun 2017 [In Indonesian]. Jurnal Hutan dan Masyarakat. 3. 1:65-77.

[33]. Alfian, R. and Kurniawan, H. 2010. Identifikasi Bentuk, Struktur, dan Peranan Hutan Kota Malabar Malang. [In Indonesian]. Buana Sains. 10. 2:195-201.

[34]. Werner, C. 2014. Green Open Spaces in Indonesian Cities: Schisms between Law and Practice. Pacific Geographies. 41:26-31.

[35]. Gunawan, H. and Sugiarti. 2015. The Role of Lido Biodiversity Park, Sukabumi as A Green Space and Conservation Area of Flora-Fauna in Urban Environment [In Indonesian]. Prosiding Seminar Nasional Masyarakat Biodiversitas Indonesia. 1. 8:1828-1835.

[36]. Handoyo, F., Hakim, L., and Leksono, A.S. 2016. Analisis Potensi Ruang Terbuka Hijau Kota Malang sebagai Areal Pelestarian Burung [In Indonesian]. Jurnal Pembangunan dan Alam Lestari. 7. 2:86-95.

[37]. Lee, Y.C. and Kim, K.H. 2015. Attitudes of Citizens towards Urban Parks and Green Spaces for Urban Sustainability: The Case of Gyeongsan City, Republic of Korea. Sustainability. 7. 7:8240-8254.
[38]. Teguh, I.G., Rachmawati, E., and Masy'ud, B. 2010. Study on Tourist Motivation and Perception to Utilization Management of Animal Tourism Object in Punti Kayu Animal Park Palembang-South Sumatra. [In Indonesian]. Media Konservasi. 15. 3:131138.

[39]. Harahap, T.K., Wirman, W., Suryadi, H., and Marta, A. 2014. Manfaat Ruang Terbuka (RTH) sebagai Sarana Interaksi Sosial dan Budaya Masyarakat di Kota Pekanbaru [In Indonesian]. In: National Conference UT 2014. 23 October 2014.

[40]. Sukara, G.N. 2014. Interpretation Planning on Birdwatching Program in The Center for Plant Conservation Bogor Botanic Garden, West Java [In Indonesian]. M.S. Thesis. Bogor Agricultural University. Indonesia.

[41]. Ando, M., Kamito, T., and Kawashima, S. 2013. Experiences of University Students with Wildlife during Pre-university Age and Their Influence on Course Selection [In Japanese]. Journal of Agricultural Science, Tokyo University of Agriculture. 57. 4:275286.

[42]. Anesaki, M. 1973. Art, Life, and Nature in Japan. Charles E. Tuttle. Japan.

[43]. Varley, P. 2000. Japanese Culture. 4th edition. University of Hawaii. Honolulu.

[44]. Totman, C.D. 1989. The Green Archipelago: Forestry in Preindustrial Japan. University of California. California.

[45]. Asquith, P.J. and Kalland, A. 1997. Japanese Images of Nature: Cultural Perspectives. Taylor \& Francis. London.

[46]. Kellert, S.R. 1991. Japanese Perceptions of Wildlife. Conservation Biology. 5. 3:297-308.

[47]. Sukara, G.N., Mulyani, Y.A., and Muntasib, E.K.S.H. 2014. Potency of Developing "Birdwatching" Tourism at Plant Conservation Center Bogor Botanic Gardens [In Indonesian]. The Botanic Gardens Bulletin. 17. 1:44-56.

[48]. Pratiwi, P.I., Furuya, K., and Sulistyantara, B. 2014. The Difference in People's Response toward Natural Landscape between University Students of Japan and Indonesia. Journal of People and Environment. 21. 2:247-253 